\title{
Art Therapy in Neurocognitive Disorders: Why the Arts Matter in Brain Health
}

\author{
Angel C Duncan* \\ Neuropsychiatric Research Center, USA
}

\section{ISSN: 2578-0379}

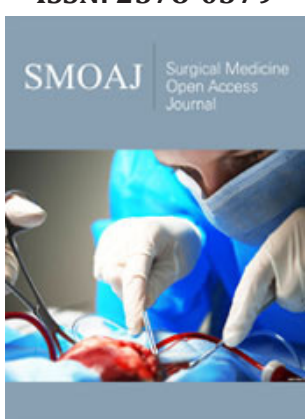

*Corresponding author: Angel C Duncan, Neuropsychiatric Research Center, USA

Submission: 崩 February 28, 2019

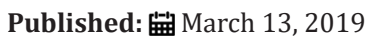

Volume 2 - Issue 3

How to cite this article: Angel C Duncan. Art Therapy in Neurocognitive Disorders: Why the Arts Matter in Brain Health. Surg Med Open Acc J.2(3). SMOAJ.000540.2019. DOI: 10.31031/SMOAJ.2019.02.000540.

Copyright@ Angel C Duncan, This article is distributed under the terms of the Creative Commons Attribution 4.0 International License, which permits unrestricted use and redistribution provided that the original author and source are credited.

\section{Mini Review}

Art has been in existence since mankind. From cave paintings to modern day society, art has been used as to tell a story, document history and provide a voice when words have become lost. We would not have the knowledge of our past had it not been for art. Medically and psychologically, art is often used for self-expression, to find an inner release and explore the process of creativity through physical and emotional pain and healing. For persons with neurocognitive impairments, such as Alzheimer's disease (AD), where memory, judgement, and reasoning are disrupted, art has been able to unlock memories thought to be lost, improve behaviors i.e. agitation, depression, and give insight into what the person may be feeling or thinking. Take for example famed artist, Willem de Kooning, some art experts may argue his brilliance as an artist was not fully recognized until his paintings became more rudimentary and abstract. What many do not know is that de Kooning was in the throes of Alzheimer's disease during his fame (Figure 1).

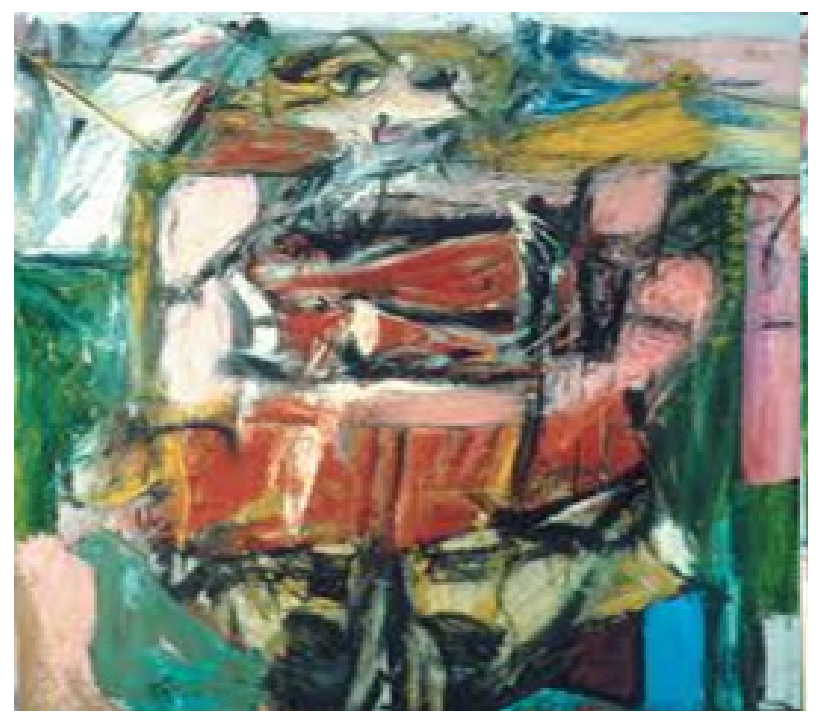

Figure 1: Willem de Kooning.

As Alzheimer's disease (AD) continues to escalate, scientists, healthcare providers and government need to start addressing this epidemic by not only supporting clinical trial research but incorporating the arts as a means of effective treatment. The quick fix is to prescribe an antipsychotic drug to control behaviour and transform these individuals into sedated androids. According to the Alzheimer's Disease International, every 3 seconds someone in the world develops dementia. The number of people living with dementia, globally, is expected to nearly double every 20 years, reaching 131.5 million people by 2050 . As amyloid and tau (the two proteins associated with AD), accumulate in the brain 20 years before noticeable symptoms are observed [1], there is a shift happening in our world where people are living longer with the number of births declining [2]. As older adults are now the largest, fastest growing population in the world, with the human lifespan expected to reach 
from 60 years of age and beyond, Alzheimer's disease is anticipated to accompanying this aging wave. The AD statics aforementioned, it is also expected that by 2050, the world's population aged 60 years and older is expected to total 2 billion, up from 900 million in 2015. By 2050 , there will be almost this many (120 million) living in China alone, and 434 million people in this age group worldwide [3].

Research efforts are underway to find effective treatments to help slow down and stop disease progression. As scientists continue to explore the organic mechanism of $\mathrm{AD}$ in the brain, gut and other bodily systems, there remains a missing answer to the question, 'What about exploring the organic mechanism of the human spirit?' Science needs art. Leonardo da Vinci stated,

"To develop a complete mind: Study the art of science; study the science of art. Learn how to see. Realize that everything connects to everything else" [4].

Some medical and health care providers are starting to embrace the arts as a form of medicine in treatment not only for persons with $\mathrm{AD}$, but also with other chronic health ailments, psychiatric disorders, and developmental disabilities. Typically, when one is discussing the arts, the right side of the brain tends to come into focus for people as the common belief is that the right side of the brain holds the artistic abilities. However, this is not so much the case as art utilizes both the right and left hemispheres of the brain.

"People don't tend to have a stronger left- or right-sided brain network. It seems to be determined more connection by connection," explained Dr. Jeff Anderson [5] (Figure 2 \& 3).

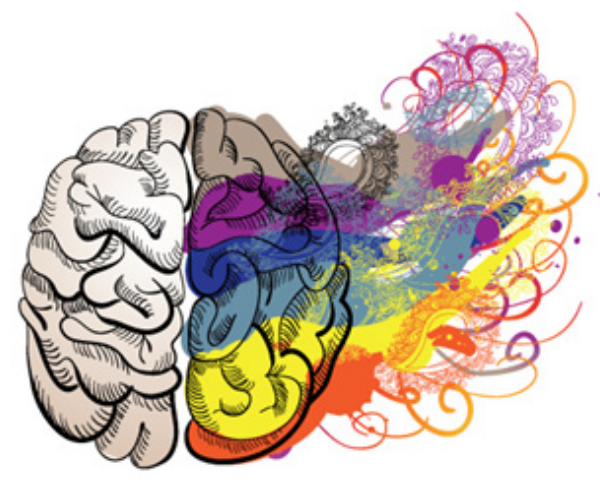

Figure 2: Dana foundation 2016 [19].

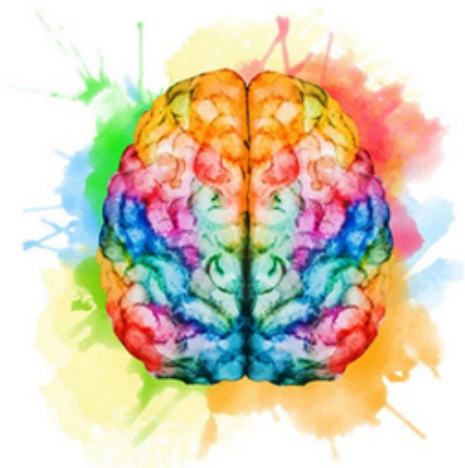

Figure 3: Hendricks 2016.
Art therapy specifically has an impact in supporting physicians in the way in which care is being delivered to their patients. Dr. Sunil Iyengar eloquently states why we need more defined research in the arts:

We all know that there's a demographic shift in baby boomers and older adults. We're having higher percentages of them in the population every day. Advances in health care have made greater longevity possible, on average, for most people. With that comes understanding that people are subject to greater health care costs down the road. People in health and medicine are looking for preventive strategies so we're not simply responding to diseases and conditions as they occur, but rather trying to prevent, or at least, delay them. It's important not only to understand how the arts can play a role in responding to specific kinds of health conditions but also to think about smart policies and funding apparatus to incentivize creativity and arts participation among older adults and also younger adults, too, as they age into these demographics [6].

Art therapy is a master's and Doctorate level degreed study of interest in the United States that is recognized in accredited universities and colleges that paves the way for an art therapist to become a registered, board certified, credentialed professional by the American Art Therapy Credentials Board [7]. In addition to the United States, other countries provide the same level of education and accreditation through their own boards. Art therapy is a mental health profession that uses the creative process of art making to improve and enhance the physical, mental and emotional wellbeing of individuals of all ages. It is based on the belief that the creative process involved in artistic self-expression helps people to resolve conflicts and problems, develop interpersonal skills, manage behavior, reduce stress, increase self-esteem and selfawareness, and achieve insight [8]. Some of the benefits that art therapy provide includes: offering a safe place for self-expression, providing a sense of well-being, learning effective coping strategies while experiencing life transitions, eliciting one's strengths and personal empowerment, providing further insight into thoughts and emotions for both the participant and the healthcare team, giving back a sense of control and autonomy to the participant, assessing further problematic areas i.e. illness and insight into emotional, physical discomforts as well as determining discharge readiness that may go unrecognized. Because of the insights and healing mechanism that art therapy provides for patients, art therapy is becoming a mainstream profession found in hospital systems, psychiatric clinics, substance abuse centers, day centers, educational institutions, homeless shelters, prisons, residential care facilities and other community-based organizations.

Along with art therapy, mindfulness practice becomes a complementary component as the two modalities go hand-in-hand. Mindfulness is the capacity to pay attention, nonjudgmentally, to the present moment. It is living in the moment, experiencing one's emotions and senses fully, yet with perspective [9]. Research validates that when engaging in creativity, there are changes in brain functioning linked to a mindfulness approach that helps to: lower blood pressure [10], provide distractions from chronic pain, 
depression, anxiety, and improve mood, increase tolerance, and give an overall sense of calm and control [11]. One of the key aspects of living in mindfulness is being present-centered, which can be a challenge for many individuals as the mind tends to wander, and rumination may occur i.e. reliving the past, or being stuck in the mind with ambiguity of the future. Persons living with AD have a way of teaching those without memory impairments about what it means to live in the present moment. In past experiences of working with those with dementia, they tend to focus on what is happening now i.e. a woman in the advanced stages of Alzheimer's gazed out the window of her residential community and spotted a butterfly. She became fixated on it, mesmerized by its beauty and swiftness. When engaging her, trying to get her to come and participate in a group discussion, she excitedly exclaimed,

"Look at the beautiful butterfly! Oh, how I love them. I see them as good luck! I'm lucky today!"

Her mindfulness practice taught a lesson in slowing down and taking in nature. That it is okay to stop for a minute and appreciate life's beauty.

The late Gene Cohen MD, founder and the first director of the Center on Aging, Health, and the Humanities at the George Washington University, conducted a longitudinal study on persons aged 65 years and older in the effects of creativity from San Francisco to Washington, D.C. He found that participants both with and without dementia had improved mood, higher morale, increased socialization, lowered medication usage and lowed number of doctor visits [12]. Creativity may play an important role in aging and conversely, the ill can express amazing light on just how the brain perceives art.

"Even though our brains age, it doesn't diminish our ability to create, even in dementia it doesn't wipe out all aspects of creativity. Indeed, people who never drew before did so, providing important clues to where the brain houses creative abilities."

Bruce Miller MD, Medical Director of Neurosciences at the University of California- San Francisco [13] (Figure 4).

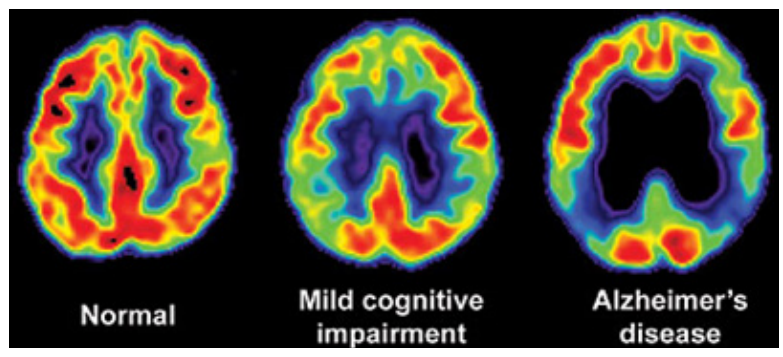

Figure 4: Science News, 2009

Art therapy can support persons living with memory impairments by enhancing their quality of life, while in a state of mindfulness that may ease behaviors, improve mood and allow for the opportunity of individuals being able to self-express themselves. Despite memory impairments caused by neural death [14], insight gained from the artwork that this population creates gives an appreciation and better understanding into their world.
The art therapist working with an individual or group is able to be an advocate for them by working with their healthcare providers. The art therapist can validate that these individuals are human, and they have thoughts, feelings and insight into their self, and world around them [15].

A woman in the advanced stages of $\mathrm{AD}$ was new to her residential care facility, and she was brought to my art therapy group to see if she would engage. As she was new to me, I welcomed her to the session and encouraged her to just have fun and paint whatever came to her mind, something that perhaps felt good to think about. She was reserved at first and repeated that she is not an artist and did not think she could paint. She sat for a moment as she watched the others painting, and as if she was in deep thought [16], she picked up the paintbrush and began to paint. The mindfulness approach took effect as she was in the present moment, focused on her art without distraction, and was fully concentrated on her work. Upon completion I processed with her, "Tell me about this beautiful art." She threw her hands over her artwork and said, "It's not good. It's no good, it looks silly." With assurance and a promise that her artwork was good and not silly, I validated that I would love to hear about it. She took her hands off it and sheepishly giggled, "I'm not an artist, but this is what I was thinking of. This is my family. My mother is here (upper left of page), my father is here (left of page in red), and I'm here (bottom right next to father). I painted myself as a child because those were my best memories. It says mommy (in black bottom right), and this is my hand reaching over my father. I loved my parents. It says, Happy. This is a good memory to think about, and I'm happy (in black on bottom left). I haven't thought about my childhood in a long time! This was fun. I enjoyed this a lot." [17] (Figure 5).

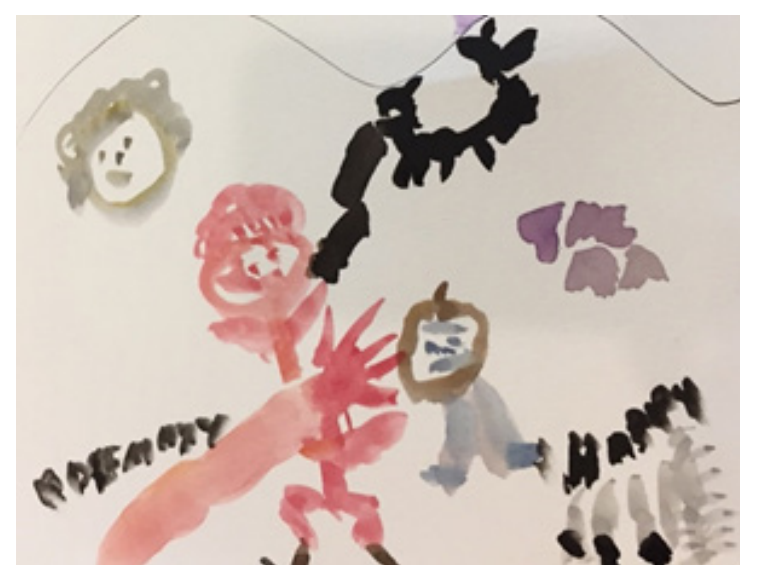

Figure 5: My family.

By giving her the opportunity to create, while thinking about a positive memory, her childhood and love of her parents surfaced. Her artwork and memory paved a way of deeper, meaningful conversation about her life. As an art therapist, I was able to connect with her on a level that simple arts and crafts or paint-by-numbers, cannot replicate. As her nurses, activity director, and occupational therapist that came in to work with her were able to observe and learn about her life, an appreciation of this woman's personhood was met. Too often, care facilities are lined with art that tends 
to all look the same, no meaning behind it, and may be seen as a pastime [18]. As art therapy differs, it is encouraged for healthcare professionals to seek out these specialists and allow their residents to have an outlet for self-expression. After all, we are human beings having a human experience and dementia does not take away from the soul $[19,20]$.

\section{References}

1. Alzheimer's Disease International (2015) Dementia statistics.

2. Rowe JW, Goldman DP, Olshansky J (2018) Effects of historically low birth rate will reverberate for years to come. The Hill.

3. World Health Organization (2018) Ageing and health.

4. Code (2014) Leonardo davinci everything connects to everything else.

5. Cherry K (2018) Left brain vs. right brain dominance: the surprising truth. Very well mind.

6. Raschke H (2016) Why research into arts and aging is crucial. Next Avenue.

7. Art Therapy Credentials Board (2019) Art therapy credentials board: ATCB home page.

8. American Art Therapy Association (2019) American art therapy association home page.

9. Kabat ZJ (2019) Guided mindfulness meditation. Home Page.
10. Weber B (2013) Mindfulness training helps lower blood pressure. Medical New Today.

11. Kane S (2018) 10 Surprising health benefits of mindfulness meditation.

12. Cohen G, Washington DC (2006) The creativity and aging study: the impact of professionally conducted cultural programs on older adults. National Endowment of the Arts, pp: 1-8.

13. Cosgrove M (2004) Creativity may help aging brains. CBS News.

14. Brenner GH (2018) Your brain on creativity: neuroscience research reveals creativity's brainprint. Psychology Today.

15. Carson SH (2009) Creativity and the aging brain use the powers of the aging brain to enhance creativity. Psychology Today.

16. King P (2016) Why are brains get less creative as we get older. Forbes.

17. Seligman M, Forgeard M, Kaufman SB (2016) Creativity and aging. Railton P, Baumeister RF, Sripada C, Seligman M (Eds.), in Oxford University Press Homo Prospectus, UK, pp: 305-312.

18. United States Census (2018) Older people projected to outnumber children for first time in U.S.

19. Dana Foundation (2016) Science meets art in new kandel book. Dana Foundation.

20. Science Daily (2009) Memory test and pet scans detect early signs of alzheimer's. Science News. 